\title{
Teenagers’ Reading Interest in an Extensive Reading Program
}

\author{
Mu He * \\ ${ }^{1}$ School of Foreign Languages and Literature, Chongqing Normal University, Jieqing Avenue Shapingba, \\ Chongqing, China \\ alily.he@connect.polyu.hk
}

Keywords: Extensive reading, Reading interest, Teenager

\begin{abstract}
This paper aims to investigate the teenagers' interest in a wide range of reading materials. Extensive reading has been gaining its popularity globally. One major requirement for the success of extensive reading is the availability of a large amount of reading materials. The academic circle makes every effort to present high-quality reading materials to ESL and EFL learner. In an extensive reading program implemented in a Shanghai secondary school, an investigation was made into teenagers' reading interest. Results show a gap between the teenagers' preference and the experts', scholars' and publishers' standards.
\end{abstract}

\section{Introduction}

Reading undeniably and incontrovertibly involves two necessary elements: a reader and a text [1]. One major requirement for the success of extensive reading is the availability of a large amount of reading materials. Due to the characteristics inherent in extensive reading, graded readers are a natural friend of extensive reading, or to be more exact, extensive reading in English, since graded readers are the resources available to EFL and ESL learners only and are mostly without parallel in other languages [2] (This has changed in the last ten years, see for example CIDEB Black Cat not only for the English language, but also for French, German, Spanish and Italian). Bamford [3] has suggested that extensive reading is by definition is the reading of graded readers. The fact is that concurrent with the spread of extensive reading is the expansion of graded readers, and various series of graded readers published by major international publishers serve as evidence of the growing acceptance of the merits of extensive reading.

The academic circle makes every effort to present high-quality graded readers to ESL and EFL learner. For instance, the Extensive Reading Foundation (ERF) (http://www.erfoundation.org) awards and promotes excellent graded reader for extensive reading every year. An international jury chose the winning book in five categories, taking into account the Internet votes and comments of students and teachers around the world. Recently it announces the launch of a new award scheme named in honour of John Milne. As creator of the Heinemann Guided Readers series in the 1970s, Milne believed that the traditional grading of vocabulary and structure was not enough to make a book suitable for language learners. He therefore took a different approach, basing his series on good, clear writing, relevant content, careful explanation and control of information, and intuitive word and structure control. These innovations have been crucial in the development of language learner literature.

\section{The survey}

It is very interesting to investigate whether the learners accept their good intentions. In an academic year, an extensive reading program using graded readers was implemented in a Shanghai senior high school. One of the research concerns of the program was the participants' preference for different genres. The books read by the participants in this program were the Oxford Bookworm (OBW) graded readers. One whole set of OBW graded readers included 235 titles distributed to seven levels, from Level(L) 0 to Level(L) 6. The distribution of the 235 title was normally 
distributed in terms of levels: 25 at L0, 41 at L1, 47 at L2, 43 at L3, 39 at L4, 21 at L5 and 19 at L6. In terms of genres, the whole series was divided into nine genres: 44 Human Interest, 36 Classics, 36 Thriller/Adventure, 31 Fantasy/Horror, 24 Crime/Mystery, 24 Factfiles, 18 True Stories, 12 World Stories and 10 Playscripts.

The sixty-six participants in this extensive reading program were stratified into two groups of thirty-three: the integration reading group and the free reading group. A comprehensive range of pre-tests had shown that the two groups were parallel in terms of overall English language proficiency, reading ability and reading levels.

Corresponding to the two groups were the two treatments: the integration reading treatment and the free reading treatment. The key pedagogical difference between the two experimental groups was that extensive reading was a medium of supplementary input for the Free Reading Group while it was a teaching methodology for the Integration Reading Group. In short, the free reading participants read out of class, and were free to choose what they were interested in. There was no class time devoted to the free reading treatment, nor was there mandatory requirement on what and how much they read. In comparison, the integration reading participants shared their reading among community via in-class discussion and part of the class time was devoted to extensive reading. To provide a basis for their in-class discussion, the researcher marked each title at the same level with a number. For instance, there were 47 titles at L2. On Monday, No.1 student read No. 1 book and No 2 student read No. 2. On Tuesday No 1 student read No 2 books and No 2 student read No 3 book. They did not need to approach the book corner; instead, they just exchanged their books day by day. The integration reading treatment differed from the standard approach to extensive reading as outlined in Day and Bamford [4] in the following distinct ways. First, there was no sustained silent reading in class. The reading was done out of class, before each session began. Second, participants were not able to choose titles, nor did they have freedom to stop reading if the title failed to interest them. In addition, the researcher required to integration reading participants to read in certain quantity every day. The extracurricular reading was part of their daily assignment, which they must finish.

When the program ended, the integration reading participants read 110.9 books on average, approximately equal to 1,141,248 words per participant. Compared with their integration reading peers, the free reading participants read much less. According to their individual reading records, they read 853 books in total, 25.8 books per student on average. The average reading amount of the Free Reading Group was 226,732 words, one fifth of that of the Integration Reading Group.

In addition to reading amount, the students' preference for different genres was counted up. The frequency statistics in Table 1 below were listed according to the choice of the Free Reading Group since the participants in this group had had the right to choose. The researcher considered that the frequency statistic of the Free Reading Group would be more objective to reflect the students' preference for genres than that of the Integration Reading Group, because the integration reading students were less lucky in this aspect as they were deprived of the right to choose what they wanted to read due to their treatment.

Table 1 Frequency of genres read by both groups

\begin{tabular}{|c|c|c|c|c|}
\hline & \multicolumn{2}{|c|}{ The Free Reading Group } & \multicolumn{2}{c|}{ The Integration Reading Group } \\
\hline Genre & Frequency & Order & Frequency & Order \\
\hline Human Interest & 154 & 1 & 592 & 1 \\
\hline Thriller/Adventure & 141 & 2 & 451 & 5 \\
\hline Fantasy/Horror & 133 & 3 & 479 & 4 \\
\hline Crime/Mystery & 107 & 4 & 329 & 7 \\
\hline Classics & 106 & 5 & 509 & 2 \\
\hline Factfiles & 96 & 6 & 506 & 3 \\
\hline True Stories & 82 & 7 & 385 & 6 \\
\hline Playscripts & 22 & 8 & 208 & 8 \\
\hline World Stories & 12 & 9 & 201 & 9 \\
\hline
\end{tabular}


The researcher was a bit concerned about the participants' preference over human interest, thriller and adventure and fantasy and horror, and their indifference toward true stories, playscripts and world stories. The OBW graded reader series read by the participants in this project had quite a few award-winning titles. In 2010, the book Playing with Fire: Stories from the Pacific Rim (L3) was awarded by ERF. The reason was: The stories are all very strong, hard-hitting and well expressed. Excellent use of illustrations by local illustrators (http://www.erfoundation.org/erf/node/67). In 2011 two titles awarded by ERF were: The Everest Story (L3), and Leaving No Footprint: Stories from South Asia (L3). The Everest Story is a true story and Leaving No Footprint: Stories from South Asia belongs to World Stories.

\section{Conclusion}

The researcher noted the gap between the teenagers' preference and the experts', scholars' and publishers' standards. The publishers have been trying to present the readers with high-quality books, and the academic circle has been renewing the standards for good readers. However, the teenagers' perception of what a good book or story seems to be different. They pay more attention to genres instead of control of information, writing quality, intuitive structure and vocabulary control, etc. This gap deserves further discussion what the readers actually acquire from their extensive reading, and what influences their English language acquisition, or whether the reading quality will be lowered if the readers miss the excellent titles in the series, and in turn interfere with the results that extensive reading would produce.

A further detailed examination of students' preference for different genres presented in Table 2 below showed that the students in the two experimental groups did not disagree with each other on the preference for different genres although the integration reading group could not choose as they wished. Undoubtedly Crime and Mystery was the most popular among them. To the researcher's surprise, world stories were not disliked by the participants. On a 5 point Liker-scale, they scored Word Stories 4.15/4.67 respectively, higher than that of Factfile and Human Interest.

The only significant disagreement between the two groups was their preference for textbooks. The Free Reading Group liked the textbook better than their integration peers. Having read much and discussed their reading in class, the Integration Reading Group showed a more negative attitude to the textbook than their peers. 
Table 2 Differences of preference for different genres between the two groups

\begin{tabular}{|c|c|c|c|c|c|c|}
\hline Genres & Group & $\mathrm{N}$ & Mean & SD & $\mathrm{F}$ & Sig. \\
\hline \multirow[t]{2}{*}{ Textbook } & IR & 33 & 3.21 & 0.99 & \multirow[t]{2}{*}{10.08} & \multirow[t]{2}{*}{0.00} \\
\hline & FR & 33 & 4.06 & 1.17 & & \\
\hline \multirow[t]{2}{*}{ Newspaper } & IR & 33 & 4.30 & 1.24 & \multirow[t]{2}{*}{0.19} & \multirow[t]{2}{*}{0.66} \\
\hline & FR & 33 & 4.42 & 1.00 & & \\
\hline \multirow[t]{2}{*}{ Magazine } & IR & 33 & 4.94 & 1.32 & \multirow[t]{2}{*}{1.50} & \multirow[t]{2}{*}{0.22} \\
\hline & FR & 33 & 5.30 & 1.07 & & \\
\hline \multirow[t]{2}{*}{ Classic } & IR & 33 & 4.64 & 1.29 & \multirow[t]{2}{*}{1.03} & \multirow[t]{2}{*}{0.31} \\
\hline & FR & 33 & 5.00 & 1.60 & & \\
\hline \multirow[t]{2}{*}{ Fantasy/Horror } & IR & 33 & 5.00 & 1.71 & \multirow[t]{2}{*}{0.02} & \multirow[t]{2}{*}{0.89} \\
\hline & FR & 33 & 5.06 & 1.87 & & \\
\hline \multirow{2}{*}{$\begin{array}{l}\text { Thriller/Adven } \\
\text { ture }\end{array}$} & IR & 33 & 4.94 & 1.60 & \multirow[t]{2}{*}{0.02} & \multirow[t]{2}{*}{0.89} \\
\hline & FR & 33 & 5.00 & 1.82 & & \\
\hline \multirow{2}{*}{ World stories } & IR & 33 & 4.15 & 1.23 & \multirow[t]{2}{*}{2.27} & \multirow[t]{2}{*}{0.14} \\
\hline & FR & 33 & 4.67 & 1.53 & & \\
\hline \multirow[t]{2}{*}{ Factfiles } & IR & 33 & 3.94 & 1.41 & \multirow[t]{2}{*}{0.66} & \multirow[t]{2}{*}{0.42} \\
\hline & FR & 33 & 4.24 & 1.60 & & \\
\hline \multirow{2}{*}{$\begin{array}{l}\text { Human } \\
\text { Interest }\end{array}$} & IR & 33 & 3.64 & 1.25 & \multirow[t]{2}{*}{0.79} & \multirow[t]{2}{*}{0.38} \\
\hline & FR & 33 & 3.97 & 1.76 & & \\
\hline \multirow[t]{2}{*}{ Crime/Mystery } & IR & 33 & 5.27 & 1.74 & \multirow[t]{2}{*}{0.00} & \multirow[t]{2}{*}{0.95} \\
\hline & FR & 33 & 5.24 & 1.84 & & \\
\hline \multirow[t]{2}{*}{ True stories } & IR & 33 & 4.58 & 1.44 & \multirow[t]{2}{*}{0.58} & \multirow[t]{2}{*}{0.45} \\
\hline & FR & 33 & 4.85 & 1.48 & & \\
\hline Playscript & IR & 33 & 4.36 & 1.56 & 0.02 & 0.88 \\
\hline & FR & 33 & 4.30 & 1.67 & & \\
\hline
\end{tabular}

Note: $\mathrm{IR}=$ the integration reading group, $\mathrm{FR}=$ the free reading group.

Textbooks are the teaching and learning resource most closely related to teachers and students. In fact the extensive reading and textbooks are not mutually exclusive. Researchers have suggested the roles that textbooks can play in extensive reading. Brown [5] suggests that textbooks should encourage extensive reading, since this will confer further legitimacy on extensive reading and may ease many of the practical difficulties that adopters of extensive reading face. He proposes both direct and indirect approaches of using textbooks to encourage extensive reading. The direct approach focuses on including extracurricular reading materials, mainly graded readers and excerpts from other written materials. The role of textbooks in the direct approach is to list a recommendation for graded readers related in some way to the topic of the unit and provide reading logs where students record the dates, book titles and pages read. The indirect approach means incorporating reading activities in ways that are more in tune with extensive reading. Jensen [6] combines authentic materials with L2 textbooks to create theme-based units that require students to read analytically. These units consist of both core readings used for intensive reading and supplementary readings available for extensive reading. The latter provide students with greater reading quantity, as well as with the responsibility of self-selecting materials. The extensive reading component also provides a place for texts too long to be read in class. He suggested that students do activities based on their extensive reading and keep a log of these activities, as extensive reading was viewed as required course work. 


\section{References}

[1] Alderson, J.C., \& Urquhart, A.H. (1984). What is reading? In J.C. Alderson \& A.H. Urquhart (Eds), Reading in a foreign language (pp. xv-xxviii). London and New York: Longman.

[2] Hill, D. R. (2008). Graded readers in English. ELT Journal, 62(2), 184-204.

[3] Bamford, J. (1984). Extensive reading by means of graded readers. Reading in a Foreign Language, 2, 218-260.

[4] Day, R.R., \& Bamford, J. (1998). Extensive reading in the second language classroom. Cambridge: Cambridge University Press.

[5] Brown, D. (2008). Why and how textbooks should encourage extensive reading. ELT Journal, 63(3), 238-245.

[6] Jensen, L. (1986). Advanced reading skills in a comprehensive course. In F. Dubin, D. E. Eskey, \& W. Grabe (Eds.), Teaching second language reading for academic purposes (pp. 103-124). Reading, MA: Addison-Wesley. 